\title{
ROLE OF POLISH MEDICAL AIR RESCUE IN NATIONAL MEDICAL RESCUE SYSTEM
}

\author{
Patryk Rzonca ${ }^{1}$, Robert Galazkowski ${ }^{2,3}$, Marcin Podgorski ${ }^{3}$ \\ ${ }^{1}$ Department of Emergency Medical Services, Medical University of Lublin, Poland \\ ${ }^{2}$ Department of Emergency Medical Service, Medical University of Warsaw, Poland \\ ${ }^{3}$ Polish Medical Air Rescue, Warsaw, Poland
}

\begin{abstract}
Great technological progression, as well as the development of motorization in the past decades, has caused an intensification of danger to health and life for contemporary societies. The increasing amount of HEMS (Helicopter Emergency Medical Service) units interventions underline that the significance of the Polish Medical Air Rescue service within the structures of National Medical Rescue System is increasing. Polish Medical Air Rescue is the one and only organization in Poland which uses helicopters while performing emergency medical services and conducting the transport of patients. The history of medical aviation, and later the Polish Medical Air Rescue service shows the great work and effort that has been put into the development and functioning of this organization.
\end{abstract}

KEY WORDS: Polish Medical Air Rescue, National Medical Rescue System, helicopter emergency medical service, pre-hospital care

Disaster Emerg Med J 2017; 2(2): 64-68

\section{INTRODUCTION}

Great technological progression, as well as the development of motorization in the past decades, has caused an intensification of danger to health and life for contemporary societies. According to WHO (the World Health Organization) ischemic heart disease, cerebral stroke, lower respiratory tract infections and COPD have been the most common causes of death for the last decade. Mortality, as a result of different causes, creates a challenge for contemporary health care systems [1]. To provide aid in Poland for every person in direct danger of their health and life, the National Medical Rescue System (NMRS) was established. The NMRS is built on two pillars, which are hospital emergency departments and medical rescue units. Apart from ground medical rescue units, the National Medical Rescue System also possesses Aeromedical Emergency Service Units which are within the Polish Medical Air Rescue service's organisational structure. The Polish Medical Air Rescue service due to its mode of transport, namely helicopters, is able to reach every region of the country within a short time. The use of aircraft has special significance in situations where the scene is unreachable for ground teams due to topography or when time of arrival to the scene poses a danger for the patient [2-4].

\section{POLISH MEDICAL AIR RESCUE - HISTORICAL OVERVIEW}

The history of medical aviation, later the Polish Medical Air Rescue service, goes back to the 1920s. The initiators of using aviation for medical purposes were doctors serving in the Polish armed forces, who frequently faced difficulties in reaching victims of war. This is why on the 8th of February 1927 the aims for national medical aviation were presented and accepted. During the period 1932-1933, the very first, Polish-produced medical airplane was manufactured. The Lublin R-XVI B was able to carry 
on board two pilots, two patients and a physician or paramedic. An additional strength of the plane was the medical equipment installed, which enabled the provision of medical care to patients during the flight. However, the greatest advantage of medical airplanes was the short time in which they could reach patients $[5,6]$.

The outbreak of the Second World War stopped the development of medical aviation in Poland. After the end of war, in 1955 medical aviation was again constituted by the Ministry of Health and Social Care. It consisted of 15 Medical Aviation Units and a Central Medical Aviation Unit, which was located in Warsaw. Combining the units within Polish territory was not coincidental and was aimed at reaching the whole area of Poland with their range. The tasks of Medical Aviation Units were as follows: transport of the ill and injured; transport of drugs and medications, blood, vaccines and medical equipment; as well as the transport of doctors and consultants in order to provide complicated surgical interventions in urgent cases. By the end of the 1960s, a new mode of transportation had appeared in medical aviation, namely helicopters [6-8].

As in airplanes, the basic team in helicopters consisted of a pilot, a hospital attendant or nurse, and in situations when, a helicopter was used, also an aviation mechanic. With the development of the medical transport of severely ill patients, paramedics from the emergency services of hospitals also appeared on board [7].

In 1999, the Central Medical Aviation Unit was terminated, with the Polish Medical Air Rescue service taking its place on 12th of May 2000, [full Polish name: Samodzielny Publiczny Zakład Opieki Zdrowotnej Lotnicze Pogotowie Ratunkowe (SP ZOZ LPR)] and was established as a successor to the tradition and experience of medical aviation in Poland. In 2000, due to a decision of the then Minister of Health, a Helicopter Emergency Medical Service (HEMS) was established. Along with changes in structure and medical aviation tasks, the organizational terms and conditions of new unit and its funding were constituted. In every position, the HEMS base employed physicians and paramedics or nurses who form the team. Helicopters were equipped with specialist medical equipment, medical devices, as well as the range of drugs and medications necessary for the medical emergency services for victims of traffic accidents and others who were in direct danger concerning their health and life. In
November 2016, SP ZOZ LPR changed its name to Lotnicze Pogotowie Ratunkowe (LPR) [7-9].

\section{STRUCTURE OF POLISH MEDICAL AIR RESCUE (PMAR)}

The Polish Medical Air Rescue service, as a unit financed directly by Ministry of Health has a unified and consistent structure, which enables it to provide medical services at the highest level. According to the law concerning the National Medical Rescue System from 8th of September 2006, PMAR is a part of the National Medical Rescue System and is treated as a unit of the system, along with hospital emergency departments and medical rescue units. According to above-mentioned law: "the Aeromedical Emergency Service team consists of at least three crew members, which comprises at least: one professional pilot, a system physician and a paramedic or a emergency nurse" [10].

The structure of PMAR consists of three elements: the LPR Operational Center (CO LPR); HEMS units; and EMS teams (Air Transport Unit) (Fig. 1).

The PMAR system consists of 21 permanent HEMS bases (Bialystok, Bydgoszcz, Gdansk, Gliwice, Gorzow Wielkopolski, Kielce, Krakow, Lublin, Lodz, Olsztyn, Opole, Ostrow Wielkopolski, Plock, Poznan, Sanok, Sokolow Podlaski, Suwalki, Szczecin, Warsaw, Wroclaw, Zielona Gora), one seasonal HEMS base (Koszalin) which operates during the summer season from 1st of June to 5th of September yearly, as well as one Air Transport Unit (EMS) located at Chopin Airport in Warsaw. The location of each base is supported by analysis of the frequency of accidents and sudden illnesses, as well as regarding

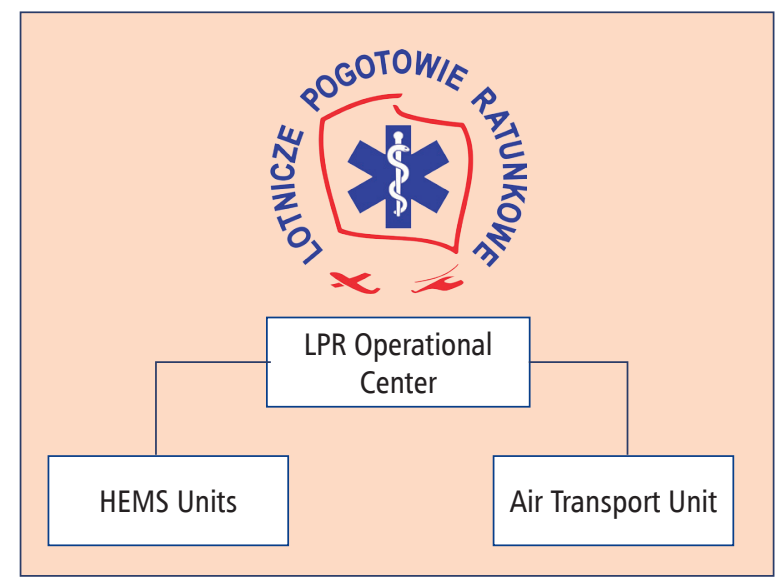

FIGURE 1. Structure of Polish Medical Air Rescue (own description based on www.lpr.com.pl) 
the time of arrival medical emergency service units in each part of the country. Due to this kind of arrangement, PMAR's helicopters can reach patients needing medical emergency services in the whole area of the country in an optimal time range (Fig. 2) $[3,11,12]$.

Moreover, at 21 HEMS bases HEMS units carry out their tasks during day time, with 4 HEMS bases operating also during night time, thus over $24 \mathrm{~h}$ (Warsaw, Krakow, Gdansk and Wroclaw). PMAR has at its own disposal two types of aircraft which are also used to perform missions. HEMS teams during their operational missions use two types of helicopters, namely the Eurocopter EC $135 \mathrm{P}+$ and EC 135 P3 which are models commonly used in HEMS units all over the world. In its missions, the Air Transport Unit uses the Piaggio P.180 Avanti turboprop airplane $[13,14]$.

\section{TASKS OF POLISH MEDICAL AIR RESCUE}

Included in the fundamental tasks of PMAR are performing emergency medical services for victims of traffic accidents and sudden illnesses, as well as carrying out the medical transport of patients requiring specialist medical care. Transports of patients requiring specialist medical care carried out between medical institutions are called inter-hospital transports. Based on statute issued by, and in agreement with the Ministry of Health, PMAR also carries out medical transports of Polish citizens from abroad who have suffered accidents and sudden illnesses [15-18].

Medical emergency services, performed by HEMS teams are carried out with a set time for readiness to take off, which depends on the distance from the scene and the time of day when the team will be disposed.

Therefore, flights to scenes of accidents and sudden illnesses are carried out during the day time with readiness to take off as follows:

- Up to 3 minutes within a radius of $60 \mathrm{~km}$;

- Up to 6 minutes within a radius of $60-130 \mathrm{~km}$;

- Up to 15 minutes within a radius of over $130 \mathrm{~km}$.

Night missions are carried out with a readiness to take off:

- Up to 15 minutes within a radius of $60 \mathrm{~km}$;

- Up to 30 minutes within a radius of over $60 \mathrm{~km}$.

According to agreements and settlements which the LPR has signed with other services cooperating within the National Medical Rescue Service, the time for readiness to take off can be extended with the time necessary to prepare the helicopter for the mission.

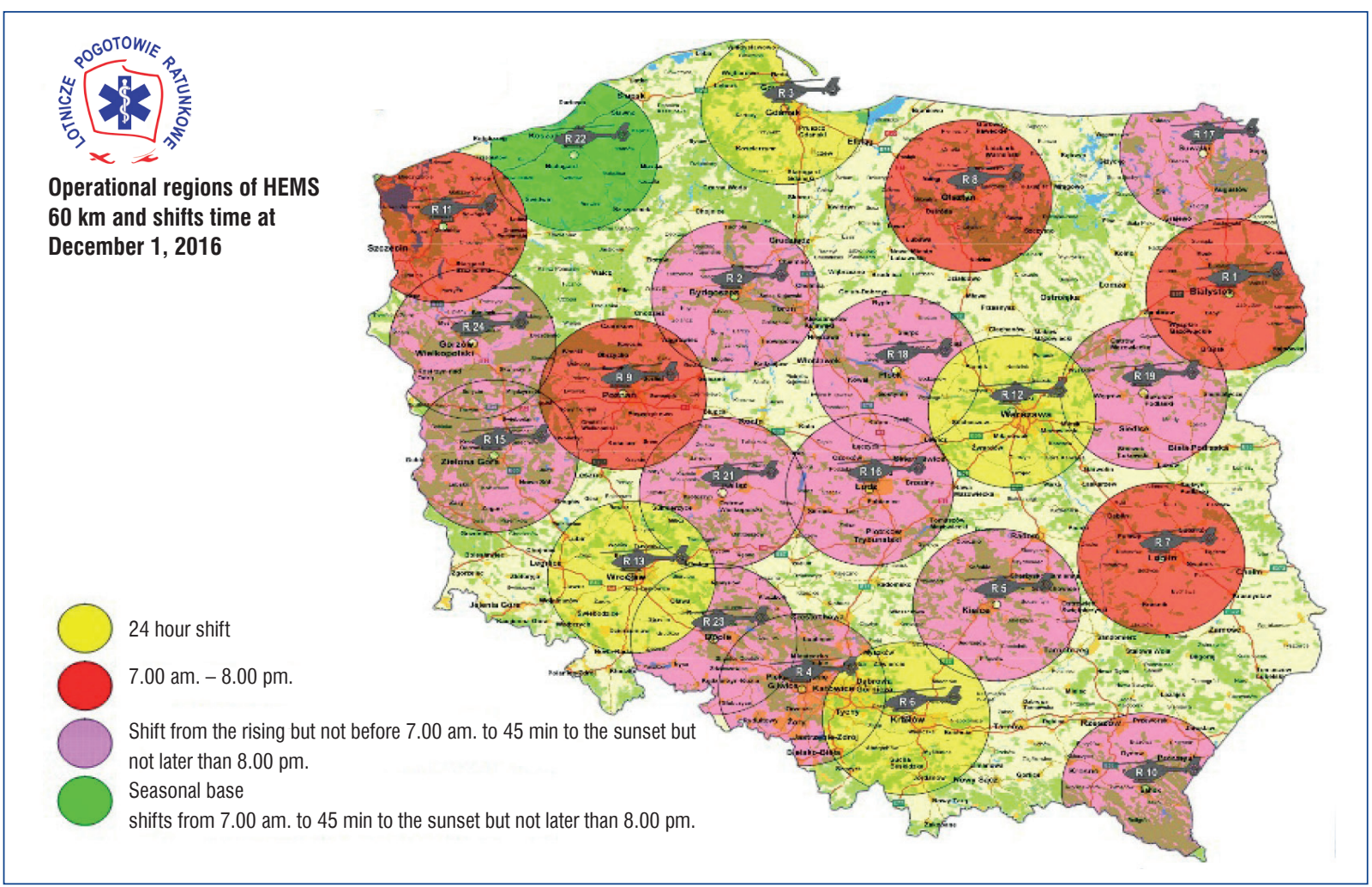

FIGURE 2. Location of PMAR HEMS bases in Poland (source: www.lpr.com.pl) 
The key to the effective use of the abilities of PMAR's HEMS teams is to dispatch them within a certain time. Included among the major reasons for dispatching aeromedical service units are:

- Fast arrival to the scene;

- Providing help to ground units;

- Lack of ground medical rescue units;

— Difficult access to the scene;

- Possibility to transport patients to specialist treatment centre;

- Possibility to transport patients to medical institutions located far away;

- Localization of the scene from the air $[15,16,19]$. During the past few years, an increasing tendency in dispatching HEMS units has been observed in Poland. This results from the development of motorization and technology in daily life, and hence increased overall trauma. In analyzing the frequency of using HEMS during the last four years, we can observe that in 2013 the smallest number of missions carried out was observed, while in 2015 the amount of missions carried out was the highest ever and exceeded 9,000 a year. However, despite the number of missions carried out per year, the dominant type of missions are flights to the scenes of accidents, followed by scenes of sudden illnesses (Fig. 3).

Among all the calls for HEMS units, the most common are as follows: traffic accidents; cerebral stroke; acute coronary syndrome; fall from a height; cardiac arrest; as well as injuries. Among the most common reasons for dispatching a HEMS team are traffic accidents, to which emergency air medical units were summoned more than 1,600 times. The second most common reason for call-outs is cerebral stroke (Fig. 4).

\section{CONCLUSIONS}

The increasing amount of HEMS units interventions underline that significance of the Polish Medical Air Rescue within the structures of National Medical Rescue System is increasing. Cooperation with emergency service units, as well as other services working within the National Emergency Medicine Service System, indicates the diversity, as well as the uniqueness of tasks performed by HEMS units, which have an established position in medical rescue systems all over the world.

The Polish Medical Air Rescue service is the one and only organization in Poland which uses helicopters while performing emergency medical services and the transport of patients. Due to the use of aircraft, HEMS teams are able to reach every place in Poland within a short time. In addition, due to fleet modernization, the fast transportation of patients, who need medical care at a specialist medical institution often located far from the scene, is possible. Thus, the speed of transport gives a chance of survival to injured patients.

The history of medical aviation, and later the Polish Medical Air Rescue service, shows the great amount of work and effort that has been put into the development and functioning of this organization. The commitment and passion of many people at every level of the organization has led to the

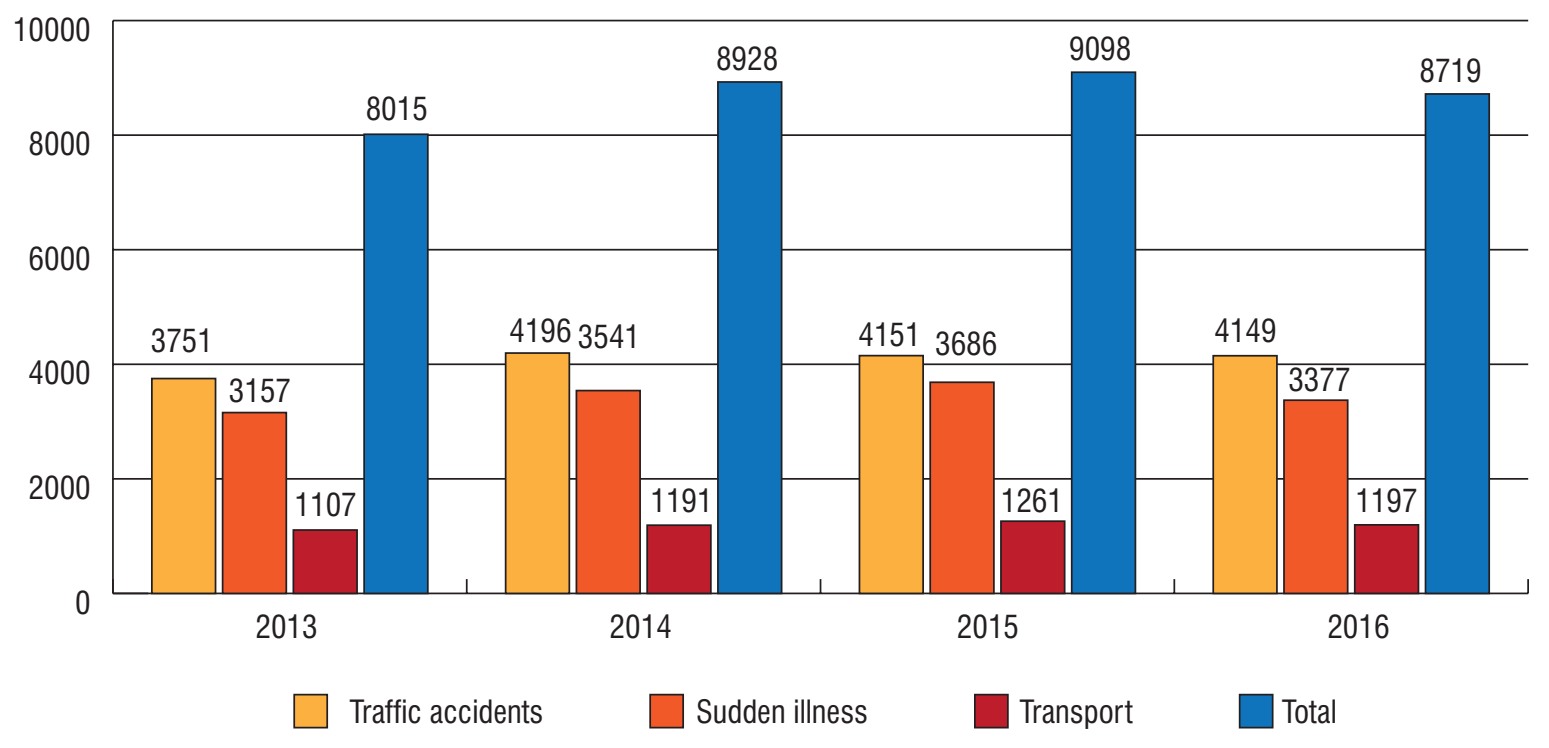

FIGURE 3. Frequency and mission type carried out by PMAR during the period 2013-2016 (own description based on materials of PMAR) 


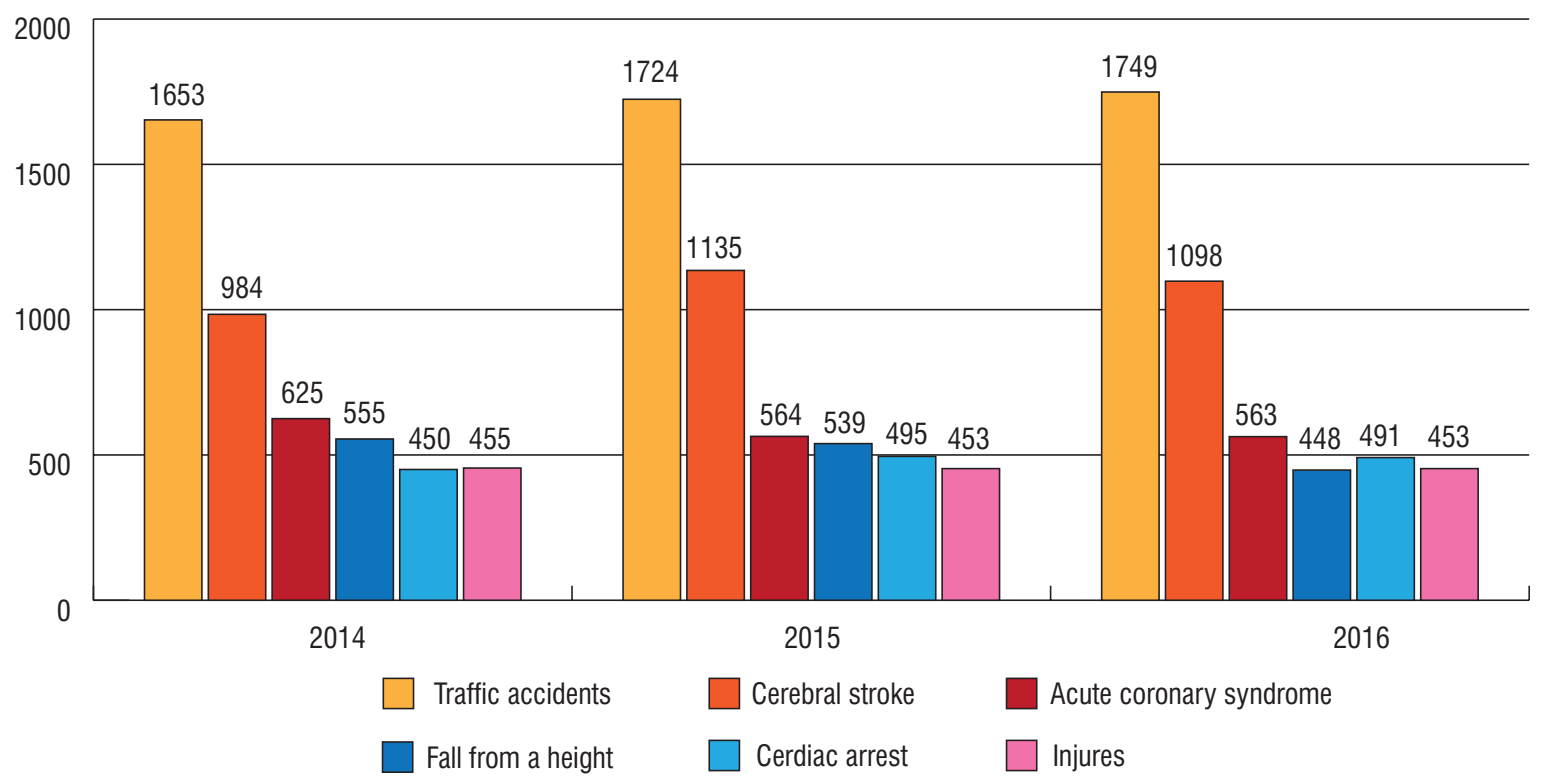

FIGURE 4. The most common causes for dispatching HEMS units during the period 2014-2016 (own description based on materials of PMAR)

emergence of an organization that is an important pillar of the medical rescue system in Poland.

Funding sources: None declared.

Conflict of interest: None declared.

\section{REFERENCES}

1. World Health Organization: The top 10 causes of death. http://www. who.int/mediacentre/factsheets/fs310/en/ (18.04.2017).

2. Ministerstwo Zdrowia: Organizacja Systemu Państwowe Ratownictwo Medyczne. http://www.mz.gov.pl/system-ochrony-zdrowia/panstwowe-ratownictwo-medyczne /organizacja-systemu-panstwowe-ratownictwo-medyczne/ (18.04.2017).

3. Ministerstwo Zdrowia: Lotnicze zespoły ratownictwa medycznego. http://www.mz.gov.pl/system-ochrony-zdrowia/panstwowe-ratownictwo-medyczne/ lotnicze-pogotowie-ratunkowe/ (18.04.2017).

4. Bauer K, Czaban SL, Gałązkowski R, et al. Lotnicze misje ratunkowe poszkodowanych z ciężkimi obrażeniami ciała w latach 2011-2012 w rejonie działania filii Lotniczego Pogotowia Ratunkowego w Białymstoku. Postępy Nauk Medycznych. 2014; 1: 55-60.

5. Kopociński Z, Kopociński K, Jeśman C. Początki lotnictwa sanitarnego w Polsce. Archiwum historii i filozofii medycyny. 2010; 73: 61-64.

6. Gałązkowski R, Kłosiński P. Polskie lotnictwo sanitarne 1955-2005. Wydawnictwo Borgis, Warszawa 2005: 20-21.

7. http://www.lpr.com.pl/pl/o-nas/historia/ (18.04.2017).

8. Ayen A. Polish Medical Air Rescue. Consolidation, Reorganization, Modernization. 4RESCUE. 2008; 3: 13-15.
9. Osiński P, Madziała M, Kopański Z, et al. Helicopter Emergency Medical Service - the past and the present. Journal of Public Health. Nursing and Medical Rescue. 2013; 1: 4-8.

10. Ustawa z dnia 8 września 2006 r. o Państwowym Ratownictwie Medycznym (Dz.U. 2006 nr 191 poz. 1410).

11. Gałązkowski R, Świeżewski SP, Rabczenko D, et al. [Rescue procedures in the major trauma of upper extremities - the role of the Polish medical air rescue in the therapeutic process]. Med Pr. 2014; 65(6): 765-776, indexed in Pubmed: 25902694.

12. Gałazkowski R. New possibilities in emergency medical transportation and emergency services of Polish Medical Air Rescue. Anestezjol Intens Ter. 2010; 42(3): 174-178, indexed in Pubmed: 21413425.

13. http://www.lpr.com.pl/pl/o-nas/ec-135/ (18.04.2017).

14. http://www.lpr.com.pl/pl/o-nas/piaggio-p-180/ (18.04.2017).

15. Gałązkowski R, Michalak G. Model realizacji lotów nocnych wykonywanych przez śmigłowce Lotniczego Pogotowia Ratunkowego. Med Og Nauk Zdr. 2012; 18(4): 383-386.

16. Gałązkowski R. Lotnicze Pogotowie Ratunkowe. Medi Press, Warszawa 2010.

17. Hawlena J, Płatek-Kępińska A, Legwant-Wójcicka M. Lotnicze Pogotowie Ratunkowe jako przykład firmy non - profit w sektorze usług logistycznych. Logistyka. 2014; 4: 402-410.

18. Jakubiak M, Sulikowska L. R12, czyli jeden dzień dyżuru w LPR. Gazeta Lekarska, 2015; 6-7. http://gazetalekarska.pl/?p=17867 (20.04.2017).

19. Gałązkowski R. Współdziałanie z Lotniczym Pogotowiem Ratunkowym. In: Guła P, Machała W. ed. Postępowanie przedszpitalne w obrażeniach ciała. Wydawnictwo Lekarskie PZWL, Warszawa 2015. 